Jurnal Teknologi Pendidikan, Vol. 9 No. 1 April 2016, p-ISSN; 1979-6692, e-ISSN: 2407-7437

\title{
PENGARUH STRATEGI PEMBELAJARAN DAN GAYA BERPIKIR TERHADAP HASIL BELAJAR BIOLOGI SISWA SMP NEGERI 2 GEBANG KABUPATEN LANGKAT
}

\author{
Suparmin Simatupang ${ }^{1}$, Efendi Napitupulu ${ }^{2}$ \\ Pascasarjana Universitas Negeri Medan ${ }^{1,2}$ \\ Suparmin_simatupang@yahoo.com ${ }^{l}$
}

\begin{abstract}
Abstrak: Tujuan penelitian ini adalah (1) untuk mengetahui perbedaan hasil belajar siswa yang diajar dengan strategi pembelajaran inkuiri dan strategi pembelajaran ekspositori, (2) untuk mengetahui perbedaan hasil belajar siswa biologi yang memiliki gaya berpikir sekuensial abstrak dan gaya berpikir sekuensial konkrit, dan (3) untuk mengetahui interaksi antara strategi pembelajaran dan gaya berpikir dalam mempengaruhi hasil belajar biologi siswa. Penelitian ini merupakan penelitian kuasi eksperimen. Hipotesis penelitian diuji dengan menggunakan Anava 2 jalur. Sebelum teknik analisis digunakan, terlebih dahulu dilakukan uji persyaratan analisis data yaitu uji normalitas dengan uji Lilliefors dan uji homogenitas varians dengan uji Bartlett dan Uji Fisher.Hasil pengujian hipotesis menunjukkan bahwa: (1) hasil belajar biologi siswa yang dibelajarkan dengan strategi pembelajaran inkuiri lebih tinggi dari pada siswa yang dibelajarkan dengan strategi pembelajaran ekspositori, (2) siswa yang memiliki gaya berpikir sekuensial abstrak memperoleh hasil belajar biologi yang lebih tinggi daripada siswa yang memiliki gaya berpikir sekuensial konkrit, dan (3) terdapat interaksi antara strategi pembelajaran dan gaya berpikir dalam mempengaruhi hasil belajar biologi siswa.
\end{abstract}

Kata Kunci: strategi pembelajaran, gaya berpikir terhadap hasil belajar biologi

Abstract: The purpose of this study were (1) to determine differences in learning outcomes of students who are taught by learning strategies of inquiry and learning strategies expository, (2) to determine differences in learning outcomes of students of biology that has style sequential thought and abstract thinking style sequential concrete, and (3) to understand the interaction between the learning strategies and thinking styles in influencing student learning outcomes biology. This study is a quasi-experimental research. The hypothesis was tested using 2-way Anova. Prior to the analytical techniques used, first tested the data analysis requirements that normality test test test Lilliefors and homogeneity of variance with Bartlett's test and test Fisher.Hasil hypothesis testing showed that: (1) the results of studying biology students that learned the strategy of inquiry learning higher of the students that learned with strategies expository, (2) students who have a thinking style sequential abstract obtain the results study biology higher than students whose style sequential thought concrete, and (3) there is no interaction between the learning strategies and style of thinking in influencing biology student learning outcomes.

Keywords: learning strategies, thinking style on learning outcomes biology

\section{PENDAHULUAN}

Salah satu upaya untuk membantu guruguru biologi di lapangan dalam melaksanakan tugasnya menuju pada pembelajaran biologi yang berorientasi pada "student centered", P3G IPA (dalam Indrawati, 1999) menawarkan strategi-strategi pembelajaran biologi yang berorientasi pada "student centered" yang dilandasi teori belajar kognitif dan yang sekarang banyak dibicarakan, diantaranya rumpun strategi-strategi pemrosesan informasi, rumpun strategi-strategi pribadi/individu, rumpun strategi-strategi sosial, rumpun strategi- strategi perilaku dan strategi pembelajaran konstruktivisme. Salah satu strategi yang digunakan dalam penelitian ini adalah strategi pembelajaran inkuiri yang merupakan bagian dari rumpun strategi pemrosesan informasi. Strategi pembelajaran inkuiri ini lebih menekankan proses pembelajaran kepada kegiatan mencari dan menemukan. Materi pelajaran tidak diberikan secara langsung. Peran siswa dalam strategi ini adalah mencari dan menemukan sendiri materi pelajaran, sedangkan guru berperan sebagai fasilitator dan pembimbing siswa untuk belajar. 
Melalui strategi pembelajaran inkuiri siswa diajak secara langsung ke dalam proses ilmiah dengan menekankan partisipasi aktif siswa dalam proses belajar. Rangkaian kegiatan pembelajaran inkuiri menekankan pada proses berpikir secara kritis dan analitis untuk mencari dan menemukan sendiri jawaban dari suatu masalah yang dipertanyakan Strategi pembelajaran inquiry ini akan mengembangkan pemikiran kritis (critical thinking), pemikiran yang reflektif (reflective thinking), dan daya kreatif yang menjadi motor penggerak aktivitas hidup yang positif, produktif, dan konstruktif (Atmadi, 2000).

Selain pemilihan strategi pembelajaran yang tepat, perolehan hasil belajar dipengaruhi oleh kemampuan guru dalam mengenal dan memahami karakteristik siswa. Reigeluth (1983), mengungkapkan bahwa hasil pembelajaran berhubungan dengan interaksi antara strategi pembelajaran dan kondisi pengajaran, yang di dalamnya termasuk karakteristik siswa. Selanjutnya Dick and Carey (1985) juga mengungkapkan hal yang sama dengan menyatakan bahwa guru hendaknya mampu untuk mengenal dan mengetahui karakteristik siswa, sebab pemahaman yang baik terhadap keberhasilan proses belajar siswa apabila guru telah mengetahui karakteristik siswanya maka selanjutnya guru dapat menyesuaikannya dengan strategi pembelajaran yang akan digunakan. Selanjutnya Bruce dalam Suparman (1997) mengemukakan bahwa para pakar pembelajaran seperti Piaget (1970), Merill (1991), dan Romiszowski (1981) menyebutkan bahwa karakteristik yang bersumber dari siswa penting untuk diperhatikan dan sangat menentukan kualitas pembelajaran dan sangat dominan dalam keberhasilan proses belajar siswa.

Salah satu karakteristik siswa yang berpengaruh terhadap hasil belajar pada penelitian ini adalah gaya berpikir. Oleh karena itu gaya berpikir siswa ini perlu menjadi salah satu kajian guru dalam merancang program pembelajaran. Perlunya mengkaji gaya berpikir ini adalah karena gaya berpikir ini merupakan cerminan dari perilaku yang relatif tetap dalam diri seseorang dalam menerima, memikirkan dan memecahkan masalah maupun dalam penyampaian informasi (Keefe, 1987). Ini berarti bahwa gaya berpikir berhubungan erat dengan bagaimana sebuah informasi diproses dan selanjutnya di simpan dalam memori yang akan menjadi ingatan jangka pendek atau ingatan jangka panjang. Dengan kata lain gaya berpikir akan mendeskripsikan bagaimana siswa memberi perhatian, menerima, menangkap, menyeleksi dan mengorganisasikan suatu informasi dari luar dirinya.

Biologi atau ilmu hayat merupakan cabang ilmu pengetahuan yang khusus mempelajari tentang proses kehidupan. Biologi akan membantu manusia untuk mengenal, mengetahui, dan memahami berbagai organisme, lingkungan serta hubungan timbal balik antara makhluk hidup dengan lingkungannya (Pardede dan Sianturi, 1995).

Kata biologi berasal dari bahasa Yunani, yaitu bios artinya hidup, dan logos artinya ilmu. Oleh karena itu, biologi dapat diartikan sebagai suatu bentuk ilmu yang mempelajari tentang makhluk hidup, air, tanah, udara, dan lain-lain yang sangat erat hubungannya dengan makhluk hidup. biologi merupakan cabang ilmu pengetahuan yang berkenaan dengan fakta yang tersusun secara sistematis, didapatkan dengan jalan studi dan praktek, serta merupakan cabang studi yang bersangkut paut dengan observasi dan klasifikasi fakta-fakta bagi tersusunnya hukum-hukum umum melalui induksi dan hipotesis (Subiyanto, 1988). Dengan demikian, biologi yang dalam wacana kurikulum pendidikan di Indonesia lebih dikenal dengan sebutan Ilmu Pengetahuan Alam (IPA) tidak cukup dipahami dari dimensi produk keilmuan berupa kumpulan pengetahuan yang memuat fakta, konsep, prinsip, hukum dan teori tentang alam semesta, tetapi juga harus mencakup proses tersusunnya pengetahuan itu berikut sistem nilai dan sikap yang menyertai kerja para ilmuwan dalam proses keilmuwannya.

Biologi merupakan mata pelajaran yang memberikan banyak kesempatan mengungkap dan mengembangkan nilai-nilai kehidupan dari retrosipasi dan antisipasi di bidang biologi manusia di didik untuk meningkatkan keahlian dalam menempuh jalan kehidupan (Wilardyo dalam Sumaji, 1998). Namun untuk dapat menguasai (memahami) biologi secara utuh sehingga mampu menangkap makna di balik fenomena alam, menuntut kemampuan yang tidak saja kritis analitis, tetapi juga kreatif imajinatif. Kemampuan berpikir kreatif yang bersumber dari cara berpikir divergen diperlukan untuk dapat menangkap hubungan dan peran antar variabel dalam gejala dan peristiwa alam. Kemudian menterjemahkannya ke dalam sistem dan pola kehidupan manusia. Misalnya, pengamatan terhadap gasing 
(gyroscope), untuk dapat menarik analogi antisipatifnya ke dinamika sosial yaitu bahwa stabilitas sosial akan tercipta dan terpelihara selama ada kebebasan yang memungkinkan masyarakat untuk berkiprah secara dinamis dalam karya kreatif yang berguna bagi kehidupan bersama, menuntut kemampuan berpikir secara holistik, berpikir dengan bersumber dan ke berbagai arah, serta kemampuan untuk mengembangkan berbagai kemungkinan, yang semua itu lebih merupakan produk dari berpikir divergen.

Pembelajaran biologi di SMP harus memperhatikan karakteristik mata pelajaran tersebut, sebab dengan memperhatikan karakteristik mata pelajaran tersebut, maka pembelajaran yang dilakukan akan efektif, efisien dan memiliki daya tarik. Adapun karakteristik biologi inilah yang membedakan biologi dengan ilmu yang lainnya. Depdiknas (2003) menjelaskan karakteristik biologi meliputi: 1) struktur keilmuan biologi yang meliputi objek berupa kerajaan (kingdom), (a) plantae (tumbuhan), (b) animalium (hewan), dan (c) protista. Ketiga objek tersebut dikaji dari tingkat molekul, sel, jaringan dan organ, individu, populasi, komunitas, sampai tingkat bioma. Adapun persoalan yang dikaji meliputi 9 tema dasar, yaitu: (a) biologi sebagai proses inkuiri/penemuan, (b) sejarah konsep biologi, (c) evolusi, (d) keanekaragaman dan keseragaman, (e) genetik dan keberlangsungan hidup, (f) organisme dan lingkungan, g) perilaku, (h) struktur dan fungsi, dan (i) regulasi. 2) tema persoalan biologi, meliputi seluruh makhluk hidup (tumbuhan, hewan, protista, monera, dan fungi). Oleh sebab itu objek yang dipelajari di biologi hendaknya meliputi kelima kingdom tersebut. 3) keterampilan proses ilmiah, tema persoalan tersebut dipelajari melalui keterampilan proses ilmiah adalah mengembangkan kecakapan hidup (life skill). 4) produk biologi, yang meliputi fakta, konsep, prinsip, prosedur, postulat, dan hukum. Produk biologi ini digunakan untuk menerangkan proses-proses kehidupan makhluk hidup, seperti proses pencernaan, respirasi, reproduksi dan perkembangan, ekskresi, koordinasi, homoestasis dan regulasi.

Mata pelajaran biologi merupakan mata pelajaran yang memberikan banyak kesempatan bagi manusia untuk merubah tingkah lakunya dalam mengungkap dan mengembangkan nilainilai kehidupan manusia, serta mendidik manusia untuk meningkatkan keahlian dalam menempuh jalan kehidupan. Perubahan perilaku itu terlihat dari hasil belajar, di mana hasil belajar tersebut tampak sebagai terjadinya perubahan tingkah laku pada diri siswa yang dapat diamati dan diukur dalam bentuk perubahan pengetahuan sikap dan keterampilan (Hamalik, 2001).

Perubahan prilaku sebagai perbuatan belajar sering disebut sebagai hasil belajar. Menurut Gagne dan Driscoll (1988) bahwa hasil belajar adalah kemampuan-kemampuan yang dimiliki siswa sebagai akibat perbuatan belajar dan dapat diamati melalui penampilan siswa (learner's performance). Pendapat Dick dan Raiser (1989) tentang hasil belajar adalah bahwa hasil belajar itu adalah kemampuankemampuan yang dimiliki siswa sebagai hasil kegiatan pembelajaran. Mereka mengemukakan hasil belajar dapat dibedakan atas empat macam, yaitu: pengetahuan, keterampilan intelektual, keterampilan motorik, dan sikap. Lebih lanjut Bloom (1976) mengemukakan bahwa hasil belajar yang menunjukkan proses perkembangan kemampuan dalam diri siswa dapat dikategorikan dalam tiga ranah, yaitu: kognitif, afektif, dan psikomotorik.

Pendapat Romizowski (1981) tentang hasil belajar bahwa hasil belajar seseorang diperoleh dalam bentuk pengetahuan dan keterampilan. Pengetahuan dikelompokkan dalam empat kategori, yaitu fakta, prosedur, konsep dan prinsip. Fakta merupakan pengetahuan tentang objek nyata, merupakan asosiasi dari kenyataan-kenyataan dan informasi verbal. Konsep merupakan pengetahuan tentang serangkaian objek konkrit atau defenisi. Prosedur merupakan pengetahuan tentang tindakan demi tindakan yang bersifat linier dalam mencapai suatu tujuan. Sedangkan prinsip adalah merupakan pernyataan hubungan antara dua konsep atau lebih yang bersifat kausal, korelasional atau sebagainya.

Dalam kalimat yang lain, Winataputra (2001) mengemukakan bahwa hasil belajar juga merupakan perubahan prilaku atau tingkah laku. Prilaku yang dimaksud berupa prilaku pengetahuan, keterampilan motorik, dan penguasaan nilai (sikap). Sementara itu, hasil belajar berupa perubahan prilaku siswa tersebut dapat diukur sebagai penilaian mutu. Penilaian mutu merupakan salah satu hal yang sangat penting bagi fungsi administrasi suatu lembaga atau organisasi. Penilaian mutu ini sering juga disebut dengan istilah kendali mutu. Kendali 
mutu ini sangat berperan dalam mengukur mutu pembelajaran yang dihasilkan suatu lembaga pendidikan.

Dalam keseluruhan proses pendidikan di sekolah, kegiatan belajar merupakan kegiatan yang paling pokok. Ini berarti berhasil tidaknya pencapaian tujuan pendidikan banyak bergantung pada bagaimana proses belajar yang dialami siswa sebagai anak didik. Menurut Ahmadi dan Supriyono (1991) menyatakan bahwa belajar adalah suatu proses usaha yang dilakukan individu untuk memperoleh suatu perubahan tingkah laku yang baru secara keseluruhan sebagai hasil pengalaman individu itu sendiri dalam interaksi dengan lingkungannya.

Winataputra (2001) bahwa belajar adalah suatu proses mental dan emosional atau proses berfikir dan merasakan. Selanjutnya Pidarta (1997) mengemukakan bahwa belajar adalah perubahan prilaku yang relatif permanen sebagai hasil pengalaman dan bisa melaksanakannya pada pengetahuan lain serta mampu mengkomunikasikannya kepada orang lain. Snelbecker (1984) mengatakan bahwa ciriciri tingkah laku yang diperoleh dari hasil belajar adalah: (a) terbentuknya tingkah laku baru berupa kemampuan aktual maupun potensial, (b) kemampuan baru itu berlaku dalam waktu yang relatif lama, dan (c) bahwa kemampuan baru itu diperoleh dari hasil usaha. Usaha untuk memperoleh kemampuan baru itu diperoleh lewat usaha belajar, berarti perubahan tingkah laku dapat disebut sebagai hasil belajar yang diperoleh sebagai hasil usaha belajar untuk dapat dimanfaatkan dalam kehidupan sehari-hari.

Gagne (1977) mendefenisikan belajar adalah perubahan dalam watak atau kemampuan manusia yang berlangsung lebih dari satu periode waktu dan tidak sama sekali dapat dianggap sebagai suatu proses pertumbuhan. Perubahan semacam ini dinamakan belajar yang diperlihatkan melalui perubahan tingkah laku dengan membandingkan tingkah laku apa yang mungkin ditunjukkan sebelum individu ditempatkan pada situasi belajar dan tingkah laku apa yang ditunjukkan setelah sejumlah perlakuan diberikan.

Strategi pembelajaran dalam konteks pembelajaran berarti pola umum perbuatan guru dan murid dalam mewujudkan kegiatan belajar. Menurut Hamalik (1993) strategi pembelajaran merupakan suatu cara, teknik atau langkah- langkah yang akan ditempuh dalam proses pembelajaran, sedangkan Romizowski (1981) berpendapat bahwa strategi pembelajaran berfungsi sebagai cara menyajikan (menguraikan, memberi contoh dan memberi latihan) isi pelajaran kepada siswa untuk mencapai tujuan tertentu. Selanjutnya Nasution dan Surianto (1991) menjelaskan bahwa strategi pembelajaran merupakan pola yang menerangkan suatu proses penyebutan dan suatu situasi lingkungan yang menyebabkan siswa berinteraksi sehingga terjadi perubahan khusus pada diri mereka. Karena merupakan alat untuk mencapai bagaimana sempurnanya materi yang disusun, bagusnya media yang ditampilkan, jika metode yang dipilih tidak tepat maka tujuan belajar itu tidak tercapai secara memuaskan. Strategi itu mencakup metode belajar yang digunakan. Ada beberapa metode yang biasa digunakan oleh guru dalam kegiatan instruksional di antaranya: ceramah, tanya jawab, diskusi, dan pemberian tugas.

Dalam proses pembelajaran diperlukan suatu strategi untuk mencapai tujuan belajar. Wiryawan, Anitah \& Nurhadi (2001) menyatakan bahwa strategi pembelajaran merupakan suatu cara yang dapat membantu tercapainya suatu tujuan dengan mengacu kepada gaya mengajar yang terkendali, seksama dengan menyusun seri - seri pengajaran yang memberikan urutan pengalaman belajar secara bertahap, yang pada akhirnya akan mencapai tujuan yang telah dirumuskan. Dalam konteks pembelajaran, strategi pembelajaran juga berarti sebagai pola umum. perbuatan guru dan siswa dalam mewujudkan kegiatan belajar. Menurut Hamalik (1993), strategi pembelajaran adalah suatu cara, teknik atau langkah-langkah yang akan ditempuh dalam proses pembelajaran. Senada dengan itu Surakhmad dalam Wiryawan, Anitah \& Nurhadi (2001) juga menyatakan bahwa strategi pembelajaran adalah sebagai cara yang dalam fungsinya merupakan alat untuk mencapai tujuan. Hal ini berlaku bagi guru (strategi mengajar) maupun bagi murid (strategi belajar), yakni makin baik strategi yang dipakai maka akan semakin efektif pula pencapaan tujuan yang akan dicapai. Bagaimanapun sempurnanya materi yang disusun, baiknya media yang digunakan, jika strategi yang dipilih tidak tepat maka tujuan belajar itu tidak tercapai secara memuaskan.

Dari uraian di atas, dapat disimpulkan strategi pembelajaran merupakan pola atau prosedur pembelajaran yang dipakai oleh guru 
dalam proses belajar yang juga merupakan pola umum perbuatan guru dan murid dalam mewujudkan kegiatan belajar. Strategi pembelajaran merupakan serangkaian kegiatan yang dirancang untuk memungkinkan terjadinya proses belajar pada siswa.

Pada dasarnya inkuiri dan discoveri saling terkait antara satu sama lain. Inkuiri yang dalam bahasa Inggris inquiry, berarti mempertanyakan, pemeriksaan atau penyelidikan. Sedangkan diskoveri artinya penemuan. Dengan melakukan penyelidikan, siswa akhirnya dapat memperoleh suatu penemuan. Strategi ini berkembang dari ide John Dewey yang terkenal dengan "'problem solving method" atau metode pemecahan masalah. Langkah dalam pemecahan masalah merupakan suatu pendekatan yang dipandang cukup ilmiah dalam melakukan penyelidikan dalam rangka memperoleh suatu penemuan. Strategi inkuiri berarti suatu rangkaian kegiatan belajar yang melibatkan secara maksimal seluruh kemampuan siswa untuk mencari dan menyelidiki secara sistematis, kritis, logis, analitis, sehingga mereka dapat merumuskan sendiri penemuannya dengan penuh percaya diri. Kegiatan pembelajaran pendekatan ini memiliki dampak positif sebagaimana yang dikemukakan Bruner dalam Hasibuan dan Moejiono (1993) yang mengemukakan bahwa pencarian (inquiry) mengandung makna sebagai berikut : (1) dapat membangkitkan potensi intelektual siswa karena seseorang hanya dapat belajar dan mengembangkan pikirannya jika ia menggunakan potensi inlelektualnya untuk berpikir; (2) siswa yang semula memperoleh extrinsic reward dalam keberhasilan belajar (mendapat nilai yang baik), dalam pendekatan inkuiri akan dapat memperoleh intrinsic reward (kepuasan diri); (3) siswa dapat mempelajari heuristik (mengolah pesan atau informasi) dari penemuan (discovery), artinya bahwa cara untuk mempelajari teknik penemuan ialah dengan jalan memberikan kesempatan kepada siswa untuk mengadakan penelitian sendiri; (4) dapat menyebabkan ingatan bertahan lama sampai internalisasi pada diri siswa.

Tujuan umum strategi inkuiri bukan pada terselesainya masalah itu sendiri, tetapi seperti yang dikemukakan oleh Joyce dan Weil (1986) ialah : "If help the students develop the intellectual discipline and skills necesarry to raise question and search answers stemming from their curiously. Strategi ini disamping mengantarkan siswa pada tujuan instruksional lingkat tinggi, dapat juga memberi tujuan iringan yaitu keterampilan memperoses secara ilmiah (mengamati, mengumpulkan dan mengorganisasikan data, mengidentifikasikan variabel, merumuskan dan menguji hipotesis, serta mengambil kesimpulan). Pengembangan daya kreatif, belajar secara mandiri, memahami hal-hal yang mendua serta sikap terhadap ilmu pengetahuan yang menerimanya secara rentatif juga merupakan tujuan dari strategi inkuiri.

Strategi pembelajaran ekspositori adalah strategi pembelajaran yang menekankan kepada proses penyampaian materi secara verbal dari seorang guru kepada sekelompok siswa dengan maksud agar siswa dapat menguasai materi pembelajaran secara optimal. Roy Killen dalam Sanjaya (2007) menamakan strategi ekspositori ini dengan istilah strategi pembelajaran langsung (direct insruction), karena dalam strategi ini materi pembelajaran disampaikan langsung oleh guru, dan siswa tidak dituntut untuk menemukan sendiri materi itu, dan materi pembelajaran seakan-akan sudah jadi atau telah dipersiapkan oleh guru.

Berpikir adalah merupakan aktivitas psikis yang intensional dan terjadi apabila seseorang menjumpai problema (masalah) yang harus dipecahkan (Ahmadi, 2003). Dengan demikian bahwa dalam berpikir itu seseorang menghubungkan pengertian yang satu dengan yang lainnya dalam rangka mendapatkan pemecahan persoalan yang dihadapi. Pendapat senada juga dikemukakan oleh Sagala (2003) bahwa berpikir sebagai proses menentukan hubungan-hubungan secara bermakna antara aspek-aspek dari pengetahuan yang diperoleh manusia. Selanjutnya Albrecht (2003) mengemukakan bahwa berpikir adalah proses menyikapi berbagai pengetahuan, baik pengetahuan berupa bentuk, suara atau rasa yang berasal dari dalam (ingatan). Pendapat yang sama juga dikemukakan oleh Award (2004) bahwa berpikir merupakan proses pengklasifikasian, perbandingan, dan penilaian terhadap pengetahuan berdasarkan kepercayaan, keyakinan, dan nilai-nilai yang tertata, lalu berubah menjadi bentuk strategi yang menghasilkan pengungkapan secara bahasa atau tindakan.

Dewey (dalam Patmonodewo dkk, 2001) mengatakan bahwa berpikir merupakan usaha dari seseorang untuk menerima dan menilai informasi-informasi berdasarkan kriteriakriteria tertentu,. Sementara itu Frenker juga dalam Patmonodewo, dkk (2001) 
mendefenisikan berpikir sebagai pembentukan ide-ide, re-organisasi dari pengalamanpengalaman seseorang dan pengorganisasian informasi-informasi ke dalam bentuk yang khas. Dari semua pendapat para ahli di atas tentang berpikir dapat diambil suatu kesimpulan bahwa berpikir merupakan suatu kegiatan mental berupa gagasan berdasarkan pengetahuan yang ada dengan memperhitungkan hubungan sebab akibat, dirangkaikan secara logis dan rasional. Sedangkan komponen dasar yang perlu dalam berpikir adalah persepsi, mengingat, membandingkan, mengkategorisasi, menghubungkan, dan pengumpulan.

Sagala (2003) menyatakan bahwa berpikir merupakan proses dinamis yang menempuh tiga langkah berpikir yaitu : (1) pembentukan pengertian yaitu melalui proses mendeskripsikan ciri-ciri objek yang sejenis, mengklasifikasikan ciri-ciri yang sama, mengabstraksi dengan menyisihkan, membuang, dan menangkap ciri-ciri yang hakiki, (2) pembentukan pendapat, yaitu meletakkan hubungan antar dua buah pengertian atau lebih yang hubungan itu dapat dirumuskan secara verbal berupa pendapat menolak, pendapat menerima atau mengiakan, dan pendapat asumtif yaitu mengungkapkan kemungkinan-kemungkinan suatu sifat pada suatu hal, dan (3) pembentukan keputusan, yaitu penarikan kesimpulan yang berupa keputusan sebagai hasil pekerjaan akal berupa pendapat baru yang dibentuk berdasarkan pendapat-pendapat yang sudah ada. Selanjutnya, Ahmadi (2003) menggolongkan jenis berpikir kedalam lima kategori, yaitu: (1) berpikir dengan pengalaman, sebagai indikator dalam pemecahan masalah, (2) berpikir representatif, yaitu berpikir dengan menggunakan ingatan dan anggapan, (3) berpikir kreatif, yaitu berpikir untuk menghasilkan sesuatu yang baru dalam kata lain menghasilkan penemuan-penemuan baru, (4) berpikir reproduktif, yaitu berpikir sesuatu dengan mencocokkannya dengan sesuatu yang telah dipikirkan sebelumnya, (5) berpikir rasional, yaitu berpikir dengan menggunakan akal sehat untuk memecahkan masalah. Dari kedua pendapat di atas dapat dinyatakan bahwa proses kegiatan berpikir pada dasarnya meliputi langkah-langkah sebagai berikut : (1) pembentukan pengertian, yaitu sebagai titik tolak untuk berpikir lebih lanjut, (2) pemahaman/identifikasi masalah yang perlu dipikirkan/dipecahkan, argumen untuk (3) penyusunan pembentukan pendapat/pemecahan masalah, dan penarikan kesimpulan /generalisasi.

Menurut DePorter dan Hernacki (2002) mengemukakan bahwa gaya berpikir adalah cara mengingat dan memperhatikan detail dengan mudah dan mengingat fakta-fakta, informasi spesipik, rumus-rumus dan berbagai peraturan dengan mudah. Sementara Tellier dalam DePorter dan Hernacki (2002) mengatakan bahwa gaya berpikir adalah cara yang konsisten yang dilakukan individu dalam mencari informasi, cara mengingat serta memikirkan cara penyelesaian suatu persoalan. Dari pendapat di atas, maka dapat disimpulkan bahwa gaya berpikir adalah cara yang dimiliki oleh individu dalam mencari, merekam dan mengingat sebuah informasi untuk digunakan dalam memecahkan suatu permasalahan.

Terkait dengan berpikir ini, Gregore (1992) membedakan gaya berpikir ke dalam dua jenis, yaitu: sekuensial (linier atau teratur) dan acak (tidak teratur) yang didasarkan pada belahan otak manusia yaitu belahan otak kiri dan kanan. Gaya berpikir sekuensial cenderung didominasi otak kiri, sedangkan gaya berpikir secara acak didominasi otak kanan. DePorter dan Hernacki (2002) menyatakan bahwa, gaya berpikir sekuensial dalam proses berpikirnya bersifat logis, teratur, linier, dan rasional. Cara berpikirnya sesuai untuk tugas-tugas teratur ekspresi verbal, menulis, membaca, menghitung, asosiasi audiotorial, menempatkan detail dan fakta, fonetik, serta simbolik. Sedangkan gaya berpikir acak, dalam aktivitas berpikirnya bersifat acak, tidak teratur, intuitif, dan holistik. Cara berpikirnya sesuai dengan cara-cara untuk mengetahui yang bersifat nonverbal, seperti perasaan dan emosi, kesadaran yang berkenaan dengan perasaan, pengenalan bentuk dan pola musik, seni, kepekaan warna, kreativitas, dan visualisasi. Selanjutnya, Chandra (2004) mengemukakan bahwa pemikir sekuensial dalam aktivitas berpikirnya cendrung bersifat objektif, presisi, aktif, logikal, verbal, penilaian, linier, konvergen, dan numerikal. Sedangkan pemikir acak dalam proses berpikirnya sarat dengan halhal yang sifatnya eksperimental, divergen, bukan penilaian, meta-forilal, subjektif, nonverbal, intuitif, diffuse, holistik, dan reseptif.

Gunawan (2004) menyatakan bahwa pemikir sekuensial mempunyai cara belajar yang khusus, yaitu : (1) menyukai hal-hal yang 
berurutan, (2) belajar maksimal dari hal-hal yang bersifat detail dulu, baru kemudian ke halhal yang bersifat global, (3) menyukai sistem membaca yang berdasarkan pada fonetik, (4) menyukai kata-kata, simbol, dan huruf, (5) menyukai sesuatu yang berstruktur dan dapat diprediksi, (6) mengalami banyak fokus internal, dan (7) ingin mengumpulkan informasi yang faktual. Demikian juga pemikir acak mempunyai cara belajar yang khusus, yaitu : (1) lebih suka dengan hal-hal yang bersifat acak, (2) belajar maksimal dari hal-hal yang bersifat global dulu, baru kemudian ke hal-hal yang bersifat detail, (3) lebih menyukai sisem membaca yang bersifat menyeluruh (whole language), (4) menyukai gambar dan grafik, (5) lebih suka melihat dulu atau mengalami sesuatu, (6) ingin mengumpulkan informasi mengenai hubungan diantara berbagai hal, (7) lebih menyukai lingkungan belajar yang bersifat spontan dan alamiah, mengalami lebih banyak fokus eksternal, dan (8) ingin pendekatan yang bersifat terbuka, baru, dan memberikan kejutan-kejutan yang menantang.

Menurut Gregore (1992) realitas bagi para pemikir sekuensial abstrak adalah dunia teori dan pemikiran abstrak. Mereka suka berpikir dalam konsep dan selalu menganalisis informasi yang diterimanya. Mereka sangat menghargai orang-orang dan peristiwa yang teratur rapi. Proses berpikir mereka cenderung logis, rasional dan intelektual. Aktivitas favorit pemikir sekuensial abstrak adalah membaca, dan jika diberi suatu masalah yang perlu diteliti, mereka akan melakukan dan menganalisisnya. Mereka ingin mengetahui sebab-sebab dibalik akibat dan cenderung menggunakan teori dan konsep dalam menyelesaikan suatu masalah. Pendapat yang sama juga dikemukakan oleh Reber (dalam Muhibbin, 2004) bahwa pemikir sekuensial abstrak berpikir rasional, dan kritis. Berpikir rasional dan kritis di sini merupakan perwujudan perilaku belajar terutama yang berbentuk pemecahan masalah. Pada umumnya siswa yang berpikir rasional akan menggunakan prinsip-prinsip dan dasar-dasar pengetahuan dalam menjawab pertanyaan bagaimana (how) dan mengapa (why). Dalam berpikir rasional siswa dituntut menggunakan logika untuk menentukan sebab-akibat, menganalisis, dan menarik kesimpulan. Dalam hal berpikir kritis, siswa dituntut menggunakan strategi kognitif untuk menguji keandalan gagasan pemecahan masalah dan mengatasi kesalahan serta kekurangan sehingga diperoleh pemahaman dan pemecahan masalah-masalah yang tidak nyata (abstrak).

Albrecht (2004) mengemukakan bahwa aktivitas favorit pemikir sekuensial abstrak adalah membaca, menulis dengan bebas, menggunakan istilah-istilah abstrak, senang akan matematika, serta konsep dan teori. Mereka memverbalkan sesuatu ke dalam bentuk susunan yang "tak nyata". Hal yang berlawanan dengan pernyataan di atas adalah pemikir sekuensial konkrit. Selanjutnya Muhibbin (2004) juga mengemukakan pendapatnya bahwa pemikir sekuensial abstrak dalam mengolah informasi cendrung menggunakan peranan akal yang kuat (logika) disamping penguasaan atas prinsip, konsep, dan generalisasi. Menurutnya pemikir sekuensial abstrak ini cocok dalam belajar matematika, kimia, kosmologi, astronomi, dan yang sejenisnya. Dryden dan Jeannette (2001) menyatakan bahwa pemikir sekuensial abstrak memiliki ciri-ciri : analitis, kritis, suka mencipta, personal, sistematis, penuh perasaan, logis, pembaca, dan suka berpikir abstrak.

Menurut Gregore (1992) orang atau individu yang mempunyai gaya berpikir sekuensial konkrit dalam aktivitas berpikirnya berdasarkan pada realitas yang mereka serap melalui indra fisik, seperti indra penglihatan, pendengaran, persentuhan, pengucapan, pengecapan dan penciuman. Individu yang bertipe sekuensial konkrit ini cenderung dalam memproses informasi dengan teratur (tahap demi tahap), berurut dan linier. Mereka lebih suka memanfaatkan yang sudah ada seperti fakta, informasi yang spesifik, rumus-rumus dan berbagai peraturan yang tersedia sebelumnya. Pemikir sekuensial konkrit dalam mengatur tugas-tugasnya cenderung tahap demi tahap dan berusaha keras untuk mendapatkan kesempurnaan pada setiap tahap. Mereka menyukai pengarahan dan prosedur khusus. Senada dengan pendapat di atas, DePorter dan Hernacki (2002) menyatakan bahwa pemikir sekuensial konkrit dalam menerima informasi cenderung membutuhkan penjelasan dan tujuan yang menyeluruh dari suatu permasalahan. Mereka memperhatikan dan mengingat realitas dengan asosiasi visual secara teliti dan detail. Pemikir sekuensial konkrit mempunyai masalah untuk mengingat intruksi secara verbal kecuali jika ditulis, dan sering kali minta bantuan orang untuk mengulanginya. Mereka sangat baik dalam membuat catatan-catatan dari informasi yang diterimanya. 
Dryden dan Jeannette (2001) mengemukakan bahwa pemikir sekuensial konkrit mempunyai ciri-ciri : realistis, teratur, langsung pada permasalahan, praktis, tepat, perfeksionis, kerja keras, perencana, penghafal, mengharapkan arahan, suka berlatih, dan selalu menuntaskan persoalan yang sedang dihadapi. Gunawan (2004) menjelaskan bahwa orang sekuensial konkrit dalam memahami sesuatu tahap demi tahap, mereka senang dengan detail. Semakin detail dan lengkap informasi yang mereka terima, semakin suka mereka jadinya. Pemikir sekuensial konkrit taat mengikuti intruksi dengan seksama dan juga sangat konsisten. Mereka hampir tidak pernah salah dalam menyampaikan detail dari suatu cerita. Mereka lebih suka akan sesuatu yang berulangulang (repetitif).

Dalam aplikasinya, untuk menentukan seseorang memiliki gaya berpikir sekuensial konkrit dan sekuensial abstrak digunakan tes baku yang dikembangkan oleh Tellier dalam DePorter dan Hernacki (2002). Tes tersebut terdiri atas 15 (lima belas) item, dimana setiap item terdiri atas 4 (empat) pilihan jawaban. Dan setiap responden diberi kesempatan untuk memilih 2 (dua) dari 4 (empat) pilihan yang tersedia. Jawaban yang diberikan oleh responden menunjukkan cara berpikir dan klasifikasi siswa. Dalam jawaban tersebut, tidak ada pilihan jawaban yang benar atau salah.

Rumusan masalah penelitian ini adalah: (1) Apakah hasil belajar biologi siswa yang dibelajarkan dengan strategi pembelajaran inkuiri lebih tinggi dari pada siswa yang dibelajarkan dengan strategi pembelajaran ekspositori?; (2) Apakah siswa yang memiliki gaya berpikir sekuensial abstrak memperoleh hasil belajar biologi yang lebih tinggi dari pada siswa yang memiliki gaya berpikir sekuensial konkrit?; (3) Apakah ada interaksi antara strategi pembelajaran dan gaya berpikir terhadap hasil belajar biologi siswa?

\section{METODE}

Penelitian ini dilaksanakan di SMP Negeri 2 Kecamatan Gebang. Pelaksanaan penelitian diawali dengan melakukan peninjauan ke lokasi penelitian untuk mengetahui secara cermat tentang keadaan jumlah kelas dan siswa kelas VII (tujuh) lyang menerima mata pelajaran biologi, latar belakang dan pengalaman guru yang memberikan mata pelajaran biologi, sarana belajar, dan kondisi kelas. Populasi adalah totalitas semua nilai yang mungkin, hasil perhitungan atau pengukuran secara kuantitatif mengenai karakteristik tertentu dari semua anggota kumpulan yang lengkap dan jelas, yang ingin dipelajarai sifatsifatnya (Sudjana, 1992). Populasi penelitian ini adalah seluruh siswa SMP Negeri 2 kecamatan Gebang yang terdiri dari 6 (enam) kelas dengan masing-masing kelas berjumlah 40 orang pada Semester II. Jadi, jumlah sampel populasi seluruhnya adalah 240 orang.

Penelitian ini menggunakan metode eksperimen semu dengan desain faktorial $2 \mathrm{x}$ 2 , sebab menggunakan kelas yang sudah terbentuk sebelumnya, dan melalui desain ini akan dibandingkan pengaruh perlakuan pembelajaran dengan menggunakan strategi pembelajaran inkuiri dan ekspositori terhadap hasil belajar biologi ditinjau dari karakteristik gaya berpikir siswa. Pembelajaran dengan strategi pembelajaran inkuiri dan ekspositori sebagai variabel bebas, dan gaya berpikir sekuensial konkrit dan abstrak sebagai variabel moderator dan perolehan hasil belajar biologi sebagai variabel terikat. Rancangan penelitian seperti pada Tabel 1 berikut:

Tabel 1. Desain Penelitian

\begin{tabular}{|l|c|c|}
\hline \multirow{2}{*}{$\begin{array}{l}\text { Gaya Strategi } \\
\text { berpikir }(\mathrm{B})\end{array}$} & \multicolumn{2}{|c|}{ Strategi Pembelajaran (A) } \\
\cline { 2 - 3 } & Inkuiri $\left(\mathbf{A}_{1}\right)$ & Ekspositori $\left(\mathbf{A}_{2}\right)$ \\
\hline Sekuensial Abstrak $\left(\mathbf{B}_{1}\right)$ & $\mathbf{A}_{1} \mathbf{B}_{1}$ & $\mathbf{A}_{2} \mathbf{B}_{1}$ \\
\hline Sekuensial Konkrit $\left(\mathbf{B}_{2}\right)$ & $\mathbf{A}_{1} \mathbf{B}_{2}$ & $\mathbf{A}_{2} \mathbf{B}_{2}$ \\
\hline
\end{tabular}

Sumber : Ferguson, G.A (1988). Statistical $\mathrm{A}_{1} \mathrm{~B}_{1}=$ Hasil belajar pendidikan biologi Analysis In Psychology and siswa yang memiliki gaya berpikir Education sekuensial abstrak dibelajarkan

Keterangan : dengan menggunakan strategi pembelajaran inkuiri. 
$\mathrm{A}_{1} \mathrm{~B}_{2}=$ Hasil belajar pendidikan biologi siswa yang memiliki gaya berpikir sekuensial konkrit dibelajarkan dengan menggunakan strategi pembelajaran inkuiri .

$\mathrm{A}_{2} \mathrm{~B}_{1}=$ Hasil belajar pendidikan biologi dari siswa yang memiliki gaya berpikir sekuensial abstrak dibelajarkan dengan menggunakan strategi pembelajaran ekspositori.

$\mathrm{A}_{2} \mathrm{~B}_{2}=$ Hasil belajar pendidikan biologi dari siswa yang memiliki gaya berpikir sekuensial konkrit dibelajarkan dengan menggunakan strategi pembelajaran ekspositori.

Teknik analisis data yang digunakan dalam penelitian ini adalah teknik statistik deskriptif dan inferensial. Teknik statistik deskriptif digunakan untuk mendeskripsikan data, antara lain nilai rata-rata (mean), median, standard deviasi (sd) dan kecenderungan data. Teknik statistik inferensial digunakan untuk menguji hipotesis penelitian, dengan teknik analisis varians Anava dua jalur (desain factorial $2 \times 2$ ) dengan taraf signifikan $5 \%$ atau 0,05. Sebelum Anava dua jalur dilakukan, terlebih dahulu ditentukan persyaratan analisis yakni persyaratan Normalitas menggunakan Uji Liliefors, sedangkan untuk uji persyaratan Homogenitas menggunakan Uji Bartlett dan uji Fisher (Sudjana, 1984). Setelah melakukan pengujian persyaratan analisis, selanjutnya dilakukan pengujian Anava 2 jalur. Anava 2 jalur ternyata signifikan, maka diadakan uji lanjut (post hoc test), menggunakan uji
Scheffe', sebab sampel tiap sel tidak sama (n tidak sama).

Adapun hipotesis statistik yang akan diuji adalah:

1. Hipotesis Pertama

Ho : $\mu \mathrm{A}_{1}=\mu \mathrm{A}_{2}$

Ha : $\mu \mathrm{A}_{1}>\mu \mathrm{A}_{2}$

2. Hipotesis Kedua

Ho : $\mu B_{1}=\mu B_{2}$

$\mathrm{Ha}: \mu \mathrm{B}_{1}>\mu \mathrm{B}_{2}$

3. Hipotesis Ketiga

Ho : $\mathrm{A}><\mathrm{B}=0$

$\mathrm{Ha}: \mathrm{A}><\mathrm{B} \neq 0$

\section{Keterangan:}

$\mathrm{A}=$ Strategi pembelajaran

$\mathrm{B}=$ Gaya berpikir siswa

$\mu \mathrm{A}_{1}=$ nilai rata-rata biologi siswa yang dibelajarkan dengan strategi pembelajaran inkuiri.

$\mu \mathrm{A}_{2}=$ nilai rata-rata biologi siswa yang dibelajarkan dengan strategi pembelajaran ekspositori.

$\mu \mathrm{B}_{1}=$ nilai rata-rata biologi siswa yang memiliki gaya berpikir sekuensial abstrak.

$\mu \mathrm{B}_{2}=$ nilai rata-rata biologi siswa yang memiliki gaya berpikir sekuensial konkrit.

\section{HASIL DAN PEMBAHASAN \\ Hasil}

Pengujian hipotesis penelitian dilakukan dengan menggunakan Anava 2 x 2. Untuk keperluan pengujian hipotesis, diperlukan Tabel pembantu perhitungan seperti di bawah ini:

Tabel 2. Tabulasi Jumlah Desain Penelitian Anava 2x2 Untuk n Tidak Sama

\begin{tabular}{|c|c|c|c|c|c|c|}
\hline $\begin{array}{l}\text { Strategi Pembelajaran } \\
\text { Gava Bernikir }\end{array}$ & \multicolumn{2}{|c|}{ Inkuiri } & \multicolumn{2}{|c|}{ Ekspositori } & \multicolumn{2}{|c|}{ Total } \\
\hline \multirow{3}{*}{ Abstrak } & $\mathrm{T}_{11}=$ & 536 & $\mathrm{~T}_{21}=$ & 381 & $\mathrm{~T}_{1}=$ & 917 \\
\hline & $\mathrm{X}_{11}=$ & 23,31 & $\mathrm{X}_{21}=$ & 18,14 & $\mathrm{x}_{1}=$ & 20,73 \\
\hline & $\mathrm{n}_{11}=$ & 23 & $\mathrm{n}_{21}=$ & 21 & $\mathrm{n}=$ & 44 \\
\hline \multirow{3}{*}{ Konkrit } & $\mathrm{T}_{12}=$ & 247 & $\mathrm{~T}_{22}=$ & 313 & $\mathrm{~T}_{2}=$ & 560 \\
\hline & $\mathrm{X}_{12}=$ & 14,53 & $\mathrm{x}_{22}=$ & 16,47 & $\mathrm{x}_{2}=$ & 15,50 \\
\hline & $\mathrm{n}_{12}=$ & 17 & $\mathrm{n}_{22}=$ & 19 & $\mathrm{n}=$ & 36 \\
\hline \multirow{3}{*}{ Total } & $\mathrm{T}_{1}=$ & 783 & $T_{2}=$ & 694 & $\mathrm{~T}=$ & 1477 \\
\hline & $\mathrm{x}_{1}=$ & 18,92 & $\mathrm{x}_{2}=$ & 17,31 & $x=$ & 36,23 \\
\hline & $\mathrm{n}=$ & 40 & $\mathrm{n}=$ & 40 & $\mathrm{n}=$ & 80 \\
\hline
\end{tabular}

Tabel 3. Rangkuman Anava 2x2

\begin{tabular}{|c|c|c|c|c|c|c|}
\hline \multirow{2}{*}{ Sumber variasi } & \multirow{2}{*}{ JK } & \multirow{2}{*}{$\mathrm{dk}$} & \multirow{2}{*}{ RJK } & \multirow{2}{*}{$\mathrm{F}$} & \multicolumn{2}{|c|}{ Ftabel } \\
\cline { 5 - 7 } & & & & & $\alpha=0,05$ & $\alpha=0,01$ \\
\hline Baris & 553,11 & 1 & 553,11 & 95,52 & 3,12 & 4,90 \\
\hline
\end{tabular}




\begin{tabular}{|c|c|c|c|c|c|c|}
\hline Kolom & 99,01 & 1 & 99,01 & 17,11 & - & - \\
\hline Interaksi & 227,35 & 1 & 227,35 & 39,27 & - & - \\
\hline Galat & 440,41 & 76 & 5,79 & & - & - \\
\hline Total & 1319,88 & 79 & & & & \\
\hline
\end{tabular}

Keterangan:

$\mathrm{KT}=$ kuadrat tengah (varians $\mathrm{JK})$

$\mathrm{JK}=$ Jumlah kuadrat

$\mathrm{dk}=$ Derajat kebebasan

\section{Pembahasan}

Proses pembelajaran yang dilaksanakan harus berorientasi kepada pemikiran bahwa siswa akan belajar lebih baik jika lingkungan diciptakan sedemikian rupa agar terasa lebih alamiah, di mana siswa menemukan sendiri pengetahuan dan keterampilan yang dibutuhkannya, dapat saling bekerja sama, bertukar ilmu pengetahuan (sharing knowledge), saling bertukar informasi, sehingga masing-masing siswa mampu menjawab persoalan-persoalan belajar yang dihadapi. Selain itu, pembelajaran yang berlangsung secara menyenangkan atau membuat suasana belajar dalam keadaan gembira akan bermuara kepada munculnya kemampuan-kemampuan yang telah dimiliki siswa pada pembelajaran sebelumnya, mengarahkan siswa untuk terlibat secara penuh, serta terciptanya makna, nilai, dan pemahaman (penguasaan atas materi yang dipelajari). Pembelajaran inquiri menekankan kepada aktivitas siswa secara maksimal untuk mencari dan menemukan, artinya strategi inkuiri menempatkan siswa sebagai subjek belajar. Dalam menerapkan strategi pembelajaran inkuiri, siswa tidak hanya berperan sebagai penerima pelajaran melalui penjelasan guru secara verbal, tetapi mereka berperan untuk menemukan sendiri inti dari materi pelajaran itu sendiri. Dalam pembelajaran inquiri seluruh aktivitas yang dilakukan siswa diarahkan untuk mencari dan menemukan jawaban sendiri dari sesuatu yang dipertanyakan, sehingga diharapkan dapat menumbuhkan sikap percaya diri (self belief). Dengan demikian, strategi pembelajaran inkuiri menempatkan guru bukan sebagai sumber belajar, akan tetapi sebagai fasilitator dan motivator belajar siswa. Aktivitas pembelajaran biasanya dilakukan melalui proses tanya jawab antara guru dan siswa. Oleh sebab itu, kemampuan guru dalam menggunakan teknik bertanya merupakan syarat utama dalam melakukan inkuiri.
Siswa dengan gaya berpikir sekuensial abstrak akan memperoleh hasil belajar biologi yang lebih tinggi jika diajarkan dengan strategi pembelajaran inquiri dibandingkan dengan jika diajarkan dengan strategi pembelajaran ekspositori. Siswa dengan gaya berpikir sekuensial abstrak dapat berkembang dengan baik, sebab gaya berpikir sekuensial abstrak membantu siswa untuk mengembangkan dan meningkatkan tingkat kecerdasannya. Siswa yang memiliki gaya berpikir sekuensial abstrak memiliki motivasi dan dorongan dalam dirinya, sehingga ia selalu berusaha untuk meningkatkan atau mempertahankan kemampuannya semaksimal mungkin dengan menggunakan standar keunggulan dengan cara menciptakan dan mengidentifikasi alternatif-alternatif pemecahan masalah, mampu untuk melakukan berbagai hal serta lancar dalam mengemukakan gagasangagasannya. Siswa dengan gaya berpikir sekuensial abstrak dapat dengan cepat beradaptasi, menyesuaikan apa-apa yang diketahui dengan apaapa yang akan dipelajarinya dalam penyelesaian soal-soal belajarnya. Siswa yang mempunyai gaya berpikir sekuensial abstrak akan terlihat dari aktivitasnya, termotivasi untuk belajar dan pada akhirnya hasil belajar yang diperoleh akan tinggi (baik). Selanjutnya, siswa dengan gaya berpikir model seperti ini cenderung berpikir secara logis, rasional dan intelektual dalam menyelesaikan soal-soal, karena mampu mengaitkan antara materi yang sudah dikuasai dengan materi yang akan dipelajari olehnya. Biasanya siswa dengan model ini jika diberi suatu masalah, maka siswa tersebut merasa perlu meneliti terlebih dahulu, selanjutnya dengan berpikir rasional, dan kritis, kemudian melakukan dan menganalisisnya. Dalam berpikir rasional, siswa secara tidak langsung siswa menggunakan logika untuk menentukan sebab-akibat, menganalisis, dan menarik kesimpulan, dan siswa akan mengolah informasi berupa konsep dan mengembangkannya, sehingga informasi yang diperolehnya menjadi nyata dan bermakna bagi dirinya.

Bagi siswa yang memiliki gaya berpikir sekuensial konkrit jika diajarkan dengan strategi pembelajaran inkuiri, akan mengalami kesulitan untuk membangun atau mengkonstruk 
pengetahuan dan keterampilan biologi yang dibutuhkannya, sebab siswa dengan gaya berpikir sekuensial konkrit memiliki tingkat kecepatan yang rendah dalam memahami, dan memaknai materi-materi esensial pelajaran biologi. Struktur kognitif siswa dengan gaya berpikir sekuensial konkrit membutuhkan waktu dan proses pembelajaran yang lebih lama untuk mencerna suatu materi pelajaran biologi yang disajikan. Siswa yang memiliki gaya berpikir sekuensial konkrit, lebih menekankan memproses segala bentuk informasi tersebut dalam bentuk apa adanya. Gaya berpikir sekuensial konkrit cenderung berpikir dengan pola yang berdasarkan realitas yang ada. Gaya berpikir sekuensial konkrit aktivitas berpikirnya berdasarkan pada realitas yang mereka serap melalui indera fisik, seperti indra penglihatan, pendengaran, persentuhan, pengucapan, pengecapan dan penciuman. Individu yang bertipe sekuensial konkret ini cenderung dalam memproses informasi dengan teratur (tahap demi tahap), berurut dan linier. Mereka lebih suka memanfaatkan yang sudah ada seperti fakta, informasi yang spesifik, rumus-rumus dan berbagai peraturan yang tersedia sebelumnya. Siswa dengan gaya berpikir sekuensial konkrit mengalami kesulitan dalam menyelesaikan soal-soal biologi yang dihadapinya, karena pengetahuan dan keterampilan yang dimilikinya berdasarkan informasi yang diberitahukan oleh gurunya, bukan karena ditemukan sendiri olehnya, dengan kata lain proses pembelajaran adalah transfer pengetahuan dari guru ke siswa. Dengan demikian, siswa dengan gaya berpikir sekuensial konkrit akan memperoleh hasil belajar biologi yang kurang maksimal.

Bagi siswa dengan gaya berpikir sekuensial abstrak, jika diajar dengan strategi pembelajaran ekspositori akan memperoleh hasil belajar yang kurang maksimal, sebab pembelajaran berbasis ekspositori berpusat pada guru (teacher-centered), di mana guru berfungsi sebagai sumber utama pembelajaran. Pada pembelajaran ekspositori tekanan utama pembelajaran untuk seluruh anggota kelas. Guru mengajar kepada seluruh siswa tanpa memandang aspek individual, biologis, intelektual, dan psikologis siswa. Guru bertindak sebagai satu-satunya sumber belajar dan sekaligus sebagai penyaji isi pelajaran. Kerjasama siswa dalam mencapai tujuan pembelajaran tidak dibutuhkan. Siswa belajar menurut kapasitasnya masing-masing,
Pembelajaran seperti ini kurang memberdayakan siswa dalam mengamati detaildetail, sehingga siswa tidak merasakan dan tidak menghasilkan bayangan-bayangan mental dan visualisasi detail dalam benaknya. Dengan demikian, tujuan pembelajaran Biologi yang sudah ditetapkan oleh guru tidak dapat berjalan dengan efektif, dan tidak sesuai dengan tujuan intruksional yang telah ditetapkan.

Sebaliknya, untuk siswa yang memiliki gaya berpikir sekuensial konkrit, jika diajar dengan strategi pembelajaran ekspositori akan memperoleh hasil belajar yang lebih baik, sebab strategi pembelajaran ekspositori adalah suatu strategi pembelajaran yang berpusat pada guru (teacher centred). Artinya, proses pembelajaran didominasi oleh guru, di mana guru berperan sebagai nara sumber dan merangsang siswa untuk mengeluarkan ide-ide atau konsep dengan pertanyaan-pertanyaan yang mudah dipahami dalam memecahkan masalah. Di akhir pembelajaran, dilakukan kegiatan tanya jawab, memberikan tugas kepada siswa untuk membuat rangkuman pelajaran yang baru diikuti dibuku catatan masing-masing dengan memberitahukan terlebih dahulu materi-materi penting pada pembelajaran yang baru dilakukan. Dengan demikian, meskipun siswa memiliki gaya berpikir sekuensial konkrit, siswa tersebut cenderung dapat menerima dan memahami makna dan esensi materi-materi penting pelajaran tersebut, sebab guru senantiasa mengarahkan dan membimbing siswa untuk memperoleh hasil belajar sesuai dengan tujuan instruksional yang telah ditetapkan. Oleh karena itu perolehan pengetahuan dan keterampilan secara sistematis yang bersumber dari guru sebagai sumber utama pengetahuan dan sekaligus penyaji isi materi pelajaran masih harus tetap dipertahankan.

\section{PENUTUP}

Berdasarkan hasil dan pembahasan penelitian yang telah diuraikan pada bab sebelumnya, maka dapat disimpulkan bahwa:

1. Terdapat perbedaan hasil belajar biologi antara siswa yang diajar dengan strategi pembelajaran inkuiri dengan siswa yang diajar dengan strategi pembelajaran ekspositori. Kelompok siswa yang diajar menggunakan strategi pembelajaran inkuiri memperoleh hasil belajar biologi yang lebih tinggi jika dibandingkan dengan siswa yang diajar strategi pembelajaran ekspositori. 
2. Terdapat perbedaan hasil belajar biologi antara siswa yang memiliki gaya belajar sekuensial abstrak dan siswa yang gaya belajar sekuensial konkrit. Kelompok siswa yang memiliki gaya belajar sekuensial abstrak memperoleh hasil belajar Biologi yang lebih tinggi dibandingkan dengan kelompok siswa yang memiliki gaya belajar sekuensial konkrit.

3. Terdapat interaksi antara strategi pembelajaran inkuiri dan gaya belajar dengan hasil belajar biologi siswa. Siswa yang memiliki gaya belajar sekuensial abstrak memperoleh hasil belajar Biologi yang lebih tinggi jika diajar dengan strategi pembelajaran inkuiri jika dibandingkan dengan diajar dengan strategi pembelajaran ekspositori. Selanjutnya untuk siswa yang memiliki gaya belajar sekuensial konkrit, memperoleh hasil belajar Biologi yang lebih tinggi jika diajar dengan strategi pembelajaran ekspositori jika dibandingkan dengan diajar dengan strategi pembelajaran inkuiri.

\section{DAFTAR PUSTAKA}

Abruscato, Joseph. (1982). Teaching Children Science. Englewood Cliffs, New Jersey : Prentice - Hall.

Agustanto, B. (2008). Pengaruh Strategi Pembelajaran dan Gaya Kognitif Terhadap Hasil Belajar Biologi SMP Negeri 4 Kecamatan Bahorok. Tesis. Medan : Program Pascasarjana Universitas Negeri Medan.

Ahmadi. (2003). Psikologi Umum. Jakarta : Rineka Cipta.

Albrecht, (2003), Brain Power, Learn to Improve Your Thinking Skills : Daya Pikir , Metode Peningkatan Potensi Berpikir. Semarang : Dahara Prize.

Arikunto, S. (2003). Prosedur Penelitian, Suatu Pendekatan Praktek. Jakarta : Rineka Cipta.

Ary, D.J. and Razavieh A. (1982). Pengantar Penelitian Dalam Pendidikan (Penerjemah : Furchan, A). Surabaya Nasional.

Atmadi, A. (2000). Transformasi Pendidikan Memasuki Millenium Ketiga. Yogyakarta : Kanisius.Ahmadi, (2003). Psikologi Umum. Jakarta : Rineka Cipta.

Award, (2004). Kembangkan Potensi Diri Anda Sepenuhnya : Kiat Meraih
Sukses Sesuai Tuntutan Islam. Yogyakarta : Mitra Pustaka.

Darajat, (2004). Pengaruh Metode Pembelajaran dan Gaya Berpikir terhadap Hasil Belajar Matematika. Tesis. Medan : Program Pascasarjana Universitas Negeri Medan.

DePorter, Bobbi dan Hernacki, Mike. (2002). Quantum Learning. Terjemah Alwiyah Abdurrahman. Bandung : Kaifa.

Dick, W., and Carey, L. (1985). The Systematic Design of Instruction. London: Scott, Foresman and Company.

Dryden dan Jeannette, (2001). Revolusi Cara Belajar : The Learning Revolution. Bandung : Kaifa.

Ferguson, G.A, (1988). Statistical Analysis In Psychology and Education, Singapura : Mc- Graw Hill International Book Company

Gagne, R.A. and Driscoll, M.P. (1988). Essential of Learning for Instruction. New Jersey : Prentice Hall Inc.

Gregore, A. (1992). An Adult's to Style, Gabriel System, Maynard.

Gunawan, (2004). Born to be a Genius. Jakarta : Gramedia.

Hamalik, Oemar. (2001), Proses Belajar Mengajar. Jakarta : Bumi Aksara.

Keefe, (1987). Learning Style: Theory and Practice. Reston Virginia National Association of Secondary School Principals (NASSP).

Merrill, MD. (1991). "A Lesson Based on The Component Display Theory" Instruction Theories in Action. Reigeluth (ed). New Jersey : Lawrence Erlbaum Ass.

Nurhadi. (2001). Tata Bahasa Pendidikan. Semarang: IKIP Semarang Press.

Pardede, C.H., dan Sianturi, P. (1995). Buku Pegangan Kuliah Mahasiswa Mata Kuliah Biologi Umum. Medan : FPMIPA IKIP Medan.

Patmonodewo,S. dkk. (2001). Psikologi Perkembangan Pribadi. Jakarta : Rineke Cipta.

Piaget J, (1970). Science of Education and the psychology of the child. New York : Wiley.

Romizowski, A.J. (1981). Design Instructional System, London: Kogan Page Ltd.

Reigeluth, C. M. (1983). Intructional Desaign Teories and Models : An Overviews of 
Their Current Status. London :

Lownrence Rrl baum Associates.

Sagala, S. (2003). Konsep dan Makna

Pembelajaran. Bandung: Alfa Beta.

Sanjaya, Wina (2007). Strategi Pembelajaran.

Jakarta : Prenada Media Group.

Snelbecker, Glen E. (1984). Learning Theory

and Instructional, Theory and

Psychoeducational Design. New York:

Mc-Graw Hill Inc Company.

Syah, Muhibbin. (1999). Psikologi Pendidikan (Suatu Pendekatan Baru. Bandung : Remaja Rosdakarya.

Tilaar, H.A.R. (2001). Manajemen Pendidikan Nasional Kajian Masa Depan. Bandung : Remaja Rosdakarya.

Winataputra, H.U.S. (2001). Strategi Belajar Mengajar. Jakarta : PPUT. 